\title{
Vector Wind Velocity, Speed, and Mode Summaries for the Southeastern U.S. (U)
}

Westinghouse Savannah River Company Savannah River Site

Aiken, SC 29808

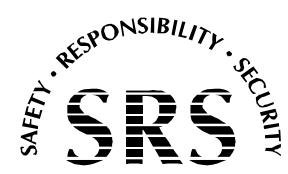

Prepared for the U.S. Department of Energy under Contract No. DE-AC09-96SR18500 
This document was prepared in conjunction with work accomplished under Contract No. DE-AC09-96SR18500 with the U. S. Department of Energy.

\section{DISCLAIMER}

This report was prepared as an account of work sponsored by an agency of the United States Government. Neither the United States Government nor any agency thereof, nor any of their employees, makes any warranty, express or implied, or assumes any legal liability or responsibility for the accuracy, completeness, or usefulness of any information, apparatus, product or process disclosed, or represents that its use would not infringe privately owned rights. Reference herein to any specific commercial product, process or service by trade name, trademark, manufacturer, or otherwise does not necessarily constitute or imply its endorsement, recommendation, or favoring by the United States Government or any agency thereof. The views and opinions of authors expressed herein do not necessarily state or reflect those of the United States Government or any agency thereof.

This report has been reproduced directly from the best available copy.

Available for sale to the public, in paper, from: U.S. Department of Commerce, National Technical Information Service, 5285 Port Royal Road, Springfield, VA 22161, phone: (800) 553-6847, fax: (703) 605-6900

email: orders@ntis.fedworld.gov

online ordering: http://www.ntis.gov/help/index.asp

Available electronically at http://www.osti.gov/bridge

Available for a processing fee to U.S. Department of Energy and its contractors, in paper, from: U.S. Department of Energy, Office of Scientific and Technical Information, P.O. Box 62, Oak Ridge, TN 37831-0062,

phone: (865)576-8401,

fax: (865)576-5728

email: $\underline{\text { reports@ adonis.osti.gov }}$ 
This page intentionally left blank. 
This page was intentionally left blank 
Vector Wind Velocity, Speed, and Mode Summaries for the Southeastern U.S.

\section{Executive Summary}

This report presents wind speed and direction summaries for a wide area of the Southeastern United States (including EPA Region 4) and portions of the Ohio and Mississippi River Valleys in a monthly time series format that is further broken down for eight hours of the day (01:00, 04:00, 07:00, 10:00, 13:00, 16:00, 19:00, 22:00 EST). The data used for these summaries were obtained from the International Station Meteorological Climate Summary (FCCA, 1996), a publicly available source of tabular data from weather stations around the world distributed through the National Climatic Data Center (NCDC). The advantage of examining the data in the form presented in this report is that it is far easier to examine and understand regional and diurnal weather patterns than would be possible with the tabular data in its original format.

The winds presented here can be viewed online in any of three formats through an Internet link. The first format is the traditional wind rose (as used in our earlier reports for 13 stations in the Southeast, c.f., Weber, Buckley, and Parker (2002) and Weber, Buckley, and Kurzeja (2003)). The second format is the mode, or most frequent wind direction sector from the wind rose plots (i.e., the longest "petal" from the individual station roses). Finally, the third format depicted is the average wind vector. The average wind vector was determined by extracting the wind speed and direction for each of the 16 sectors from a station's wind record and then summing components of these vectors for the month and time of observation. Each station was then plotted on a sequence of maps for the Southeastern U.S. using ArcView software. These maps form a time series in 3-hour increments showing changes in vector wind speed and direction for each month of the year. The complete set of color figures are too numerous to be included in this report, but may be accessed by contacting one of the authors.

\section{Introduction/Data Processing}

This report is a continuation of previous work on wind rose depictions for the Southeastern U.S. that the authors and others completed for a more limited geographical area. A main difference between the previous reports and this work is that the area analyzed and plotted extends west to Fort Smith, Arkansas; north to Columbus, Ohio; and south to Key West, Florida. Thus, we can now examine wind roses for the western side of the Appalachians, the Gulf Coast, and the Mississippi and Ohio River Valleys, in addition to the region of the Southeastern U.S. shown in the earlier work.

Some 58 National Weather Service (NWS) stations in the Southeastern U.S. were selected for analysis. These stations are listed in Table 1 along with the location, latitude, longitude, elevation, and period of record as recorded on the FCCA data disk. The stations with an asterisk (*) in Table 1 have wind rose statistics recorded in the Central Standard Time (CST) zone. All the remaining stations report have their data recorded in Eastern Standard Time (EST). The reason that some of the stations in Table 1 appear to be out of their 
normal time zone is due to an early reporting convention established by the National Climatic Data Center.

The wind data from the frequency tables contained on the FCCA disk are frequency of occurrence of six wind speed ranges, along with the mean (scalar) speed in each of 16 wind direction sectors for each 3-hour period. Traditional wind roses figures can be constructed from these tables by drawing wind rose "petals" whose lengths represent the frequency of occurrence of the wind for these sixteen sectors. The petals are segmented with colors to represent wind speed bins proportional to the frequency of occurrence of six wind speed range bins.

The vector averages are different from the traditional wind roses in that all the information in the tables is reduced to one vector or petal of the rose. This petal represents the net effect of the wind blowing for that particular 3-hr time period during the month being examined. The vector average is determined by taking the scalar average speed for each direction sector (of 16) and projecting its components along east-west and north-south axes. Then, the magnitude (or speed) of the vector average is found by summing the components (weighted by the frequency of occurrence) and taking the square root of the sum of the squares of the components. Finally, to account for the percentage of calm winds and to scale the results for plotting, the following formulae were used,

$$
S=\left(1-P_{C A L M} / 100\right) \sqrt{U_{T o t}^{2}+V_{T o t}^{2}}
$$

and

$$
S_{S C A L E D}=\frac{S}{10}
$$

where $P_{C A L M}$ is the percentage of calms reported for the station for the particular month and time of day, $U_{T o t}$ and $V_{T o t}$ are the sums of the vector components (as described above), and $S$ is the average magnitude of the vector wind. This method accounts for the calm (or zero) wind speeds by reducing the speed according to the fraction of calm winds. The quantity $S_{S C A L E D}$ is the scaled value of the wind to accommodate plotting the wind roses with the ArcView software in the layout provided. The average vector speed is then assigned a bin and color-coded according to (0-2, 2-4, etc. knots).

The vector's average direction angle is found by finding the inverse tangent of the ratio of the summed north-south and east-west components. The average wind direction angle is then used to determine the appropriate 22.5 degree sector among the 16 possibilities of the full circle. This process is repeated for each of the eight time periods of the day and 12 months of the year for the years of record at each station. The average vector for each station is then plotted on a background map with the aid of ArcView GIS software. 


\section{Wind Plots}

The average wind vector plots are made with ArcView software with our previously established choices of colors for the "petals" corresponding to particular wind speed ranges. The wind directions are assigned as usual to one of the sixteen compass sector ranges to represent the direction from which the wind blows (Table 2).

No blues or blacks were visible among the complete set of plots for the 12 months and eight hours of the day, so the average vector for all 58 stations in each case was less than (or at most) 10.5 knots for all of the 16 compass sectors N, NNE, NE, ENE, E, ESE, SE, SSE, S, SSW, SW, WSW, W, WNW, NW and NNW (22.5 degrees in each sector).

The average wind vector can be interpreted as the net airflow at the given time of day for a particular station. For example, if the wind tables showed only two directions, north and south, and these winds occurred with equal frequency and wind speed classes, the net air flow would be zero and the wind vector would be zero. On the other hand, if the frequency of occurrence of one of the two directions in this example dominates the other, the net flow (vector) would lie in that direction. In our plots there were a few cases where the net flow was approximately zero, i.e., essentially a dot on the plot. Normally when a station's traditional wind rose is predominately from a group of contiguous sectors, the average wind vector will be from that sector. But this is not necessarily always the case, since sectors with larger speeds can offset sectors with low speeds. A reason for examining the mean vector wind is that more often these vectors show spatially coherent patterns and sensible time evolution than can be seen with modes or traditional wind roses.

The wind mode is a more straightforward interpretation than the net vector. It is merely the longest "petal" of the wind rose, meaning it is the most frequent wind direction sector at a given station. The color of the petal for the wind mode in the plots was fixed to be red. The length of the petal corresponds to the frequency of occurrence of that wind direction from the original wind rose, i.e. the larger the frequency of occurrence of winds from a particular compass sector, the longer the petal will be.

Traditional wind roses have proved to be valuable in the past giving forecasters useful, added insight for difficult wind forecasts, especially where National Weather Service models disagree or where predicted wind speed is light. 


\section{Discussion of Results}

\section{A. Examples of Plots}

Since each combination of month and time of day can be plotted in one figure, we have a total of 12 months $\times 8$ periods of the day $\times 3$ types of plots (traditional rose, mode, vector average), or 288 figures. This number is too large to include and discuss in this report; instead, we elected to make the complete collection of figures available on the Internet and to discuss a few examples, leaving readers to examine the complete set of figures as time permits.

We begin with an example of the vector average wind roses shown for April, 16:00 EST (reporting time) in Fig. 1. This figure shows the existence of sea breeze conditions along the Gulf of Mexico and Florida's east coast, with southwest to west-southwest flow in most inland areas, and stronger net transport in and near the Appalachians.

Figure 2 shows the mode plot for the same month and time of day as Fig. 1. Figure 2 indicates some inland directed modes along the coasts and mainly northerly directed modes along the Mississippi River Valley. Major flow features can be seen around the Appalachians, but differences from the vector average exist. For example, note that AGS, $\mathrm{AHN}$, and ATL most frequently experience west-northwest winds while the vector average is west-southwest. This may be due to the frequent occurrence of west-northwest winds at night that has been noted even on SRS Area Towers (C. Hunter, personal communication). The west-southwest winds in the vector average may be due to pre-frontal conditions during which winds tend to be stronger in this geographical area, especially in the spring time.

\section{B. Complete results}

We now describe the results from our analysis of all of the months and times of day. For convenience, we break up the discussion into eight periods of the day and six regions. The regions are defined in Table 3 and shown in Fig. 3.

Table 4 shows summaries of the wind vector plots for the sub-regions in Table 3. Each 3hour time period and sub-region was assigned an overall wind direction from among the 16 compass sectors for each month. Three special categories (SLB = sea breeze, meaning there is no predominant direction for all stations, but there is flow from sea to land or land to sea in all cases; $\mathrm{CF}=$ coastal following, meaning there is no predominant direction, but each vector seems to be following the coastal contour; and $\mathrm{MX}=$ mixed; meaning there is no predominant direction and no spatial coherance) were assigned. Table 5 contains similar information as gathered for the mode of each station.

The summaries in Tables 4 and 5 were accomplished by examining the plots and subjectively determining the overall wind direction for each sub-region. The reader may find it easier to follow the changes in wind direction with plots than by examining tables. 
Figures 4 to 15 show time variations in wind vector averages and modes for each subregion.

Figure 4 shows the time evolution of vector winds for the East Coast stations. The winds between 01:00 and 13:00 LST for these stations show a northwesterly flow in the winter months (probably due to extratropical cyclones) that gradually turns southwesterly by August (probably due to the Bermuda high-pressure system). The winds in September show a mixed result, but by October they have returned to northerly in the morning hours or northeasterly in the afternoon then northwesterly in the morning in November and December. Figure 5 illustrates the corresponding time evolution of the mode for the East Coast stations. The winds between 01:00 and 07:00 LST for these stations show a southwesterly flow in the spring months. The winds in September and October become northeasterly due to the high-pressure system that is often over the Ohio Valley or the Appalachians in the fall.

The time evolution of vector winds for the Piedmont Stations is shown in Fig. 6. The daytime (between 07:00-16:00) winds show west or northwesterly flow in the winter months that gradually turn southwesterly by July. The winds in August show a mixed result (breakdown of this regime) but by September the winds have become NNE, then northerly in October. The nighttime (17:00-00:00) winds show a progression by month from westerly to southwesterly to south then southeast in August, followed by a relatively sudden change to northeasterly in September. The primary forcing causing this change is the Bermuda high-pressure system in summer being replaced by the Ohio-Appalachians high pressure system in autumn, and extratropical cyclones in winter. The corresponding modes (Fig. 7) are mostly mixed except that they demonstrate either southwesterly flow between 01:00 and 13:00 LST or northeasterly flow from 04:00 to 19:00 LST in September and November.

Figures 8 and 9 show the time evolution of vector winds and mode for the Appalachian stations. Since these stations are dramatically terrain influenced the predominant summary is mixed. However, during the afternoon (13:00 - 19:00 LST) there is a fairly constant westerly component to the vector average winds. The shift to northeast in September is not as universal for these stations as it is for the Piedmont. The early morning and evening vector average winds are mostly northwesterly in the winter months. Again the mixed mode in nearly every time period implies the dramatic influence of terrain.

The time variation in vector winds for the Mississippi Valley stations is indicated in Fig. 10. These stations seem to show a predominant southerly flow for the spring and summer months during all times of day. This may be due to a thermal low over the continental U.S. in the summertime or due to the circulation pattern in the western portion of the Bermuda high pressure system. At nighttime in the late fall and winter the flow becomes easterly over this section of the country, probably again due to the high-pressure system over the Ohio Valley and Appalachians. Time-variations in mode (Fig. 11) show that whenever the stations are not categorized as mixed, they seem to be dominated by southerly flow for all months and times of day. 
Figure 12 shows the time evolution of vector winds for the Ohio Valley stations. These stations are rather unique in that they show no northeasterly net vectors. The predominant mode is west, southwest, or south, with only three occurrences of winds from the southeast. During midday the flow is predominantly southwesterly throughout the year. This is probably due migratory low-pressure systems moving in from the Midwest to the Ohio Valley. The corresponding mode variations shown in Fig. 13 indicate none coming from the northeast. The predominant mode is southwest or south with no occurrences of southeast. At midday the predominant southwesterly modes persist except in winter.

Finally, Gulf Coast station time variations in vector averaged winds are shown in Fig. 14. The daytime winds (13:00 - 19:00 LST) show sea breezes during the spring and summer months. In fall and winter the flow is more likely to be from the northeast, whereas summer's flow at 01:00 LST is from the southeast. For the modes (Fig. 15), the daytime winds after 13:00 LST are sea breezes during the spring and summer months. In the morning hours during fall the flow is more likely to be from the northeast.

\section{Conclusions/Future Work}

The wind statistics are presented in three forms that can be accessed on the Internet. The URLs are available from the authors. There are three groups of plots; first, traditional wind roses; second, the mode or the direction sector with the largest frequency of occurrence; third, the net wind vector, a single vector representing the net flow at a particular station during the month and 3-hr time period specified.

The winds are controlled by semi-permanent pressure systems off the Southeast Coast and inland as well. The Bermuda high influences the winds in the spring and summer periods. The high-pressure system over the Ohio Valley and/or Appalachians controls the winds during fall, and migratory low-pressure systems from the Midwest influence the flow during summer for stations in the Ohio Valley. The land-sea breeze circulation affects the coastal stations along the East and Gulf Coasts.

More work should be done to exploit the predictive capabilities of these results. For example, by determining the net flow for a group of stations in a sub-region, one might be able at any given time of the year to determine if a net vector wind or transport of heat had been achieved. If so, then the climatic average might be expected. If a region were above or below its average net flow, then higher or lower flow from the excess/deficient direction sectors might be expected. 


\section{References}

FCCA, 1996: International Station Meteorological Climate Summary, Version 4.0, (compact disk) Federal Climate Complex, Asheville, NC.

Weber, A. H., R. L. Buckley, and M. J. Parker, 2002: Wind Climate Analysis for National Weather Service Stations in the Southeast (U), WSRC-TR-2002-00515, Westinghouse Savannah River Company, Savannah River Site, Aiken, SC, 29808, 60 pp.

Weber, A. H., R. L. Buckley, and R. J. Kurzeja, 2003: Wind Climate Analysis for SRTC's Central Climatology Site (U), WSRC-TR-2003-00141, Westinghouse Savannah River Company, Savannah River Site, Aiken, SC, 29808, 59 pp.

Weber, A. H., R. L. Buckley, M. J. Parker, and M. E. Brown, 2002: Wind Speed and Direction Analyses for a Group of Southeast Surface Stations. Proceedings American Meteorological Society Annual Meeting, $13^{\text {th }}$ Symposium on Global Change and Climate Variations, Orlando, FL, Jan 17, 2002. 


\section{List of Tables}

1. National Weather Service stations selected for analysis.

2. Speed range and color-code for vector wind rose figures. 8

3. Southeastern U.S. sub-regions used for discussion of diurnal wind variations. $\quad 8$

4. Diurnal wind summaries for the vector average by sub-region of the Southeastern U. S. (16 compass points: N, NNE, ..., NNW; MX implies mixed results, SLB implies sea/land breeze, and CF implies winds following the coastal contour).

5. Diurnal wind summaries for the mode by sub-region of the Southeastern U. S. (16 compass points: N, NNE, ..., NNW; MX implies mixed results, SLB implies sea/land breeze, and CF implies winds following the coastal contour). 
Table 1. National Weather Service stations selected for analysis.

\begin{tabular}{|c|c|c|c|c|c|c|}
\hline Station & City & State & LAT $\left({ }^{\circ}\right.$ min $)-\mathrm{N}$ & LON ( ${ }^{\circ}$ min $)-W$ & Elevation (ft) & Period of Record \\
\hline AGS & AUGUSTA & GA & 3322 & 8158 & 148 & 1949-1995 \\
\hline $\mathrm{AHN}$ & ATHENS & GA & 3357 & 8319 & 802 & $1955-1995$ \\
\hline AQQ & APALACHACOLA & FL & 3339 & 8426 & 20 & 1945-1995 \\
\hline ATL & ATLANTA & GA & 2944 & 8502 & 1010 & 1948-1992 \\
\hline AVL & ASHEVILLE & $\mathrm{NC}$ & 3526 & 8233 & 2140 & 1948-1995 \\
\hline BHM & BIRMINGHAM & AL & 3334 & 8645 & 620 & $1948-1995$ \\
\hline BNA* & NASHVILLE & $\mathrm{TN}$ & 3607 & 8641 & 580 & 1948-1995 \\
\hline $\mathrm{BTR}^{*}$ & BATON ROUGE & LA & 3032 & 9108 & 64 & 1948-1995 \\
\hline CAE & COLUMBIA & $\mathrm{SC}$ & 3357 & 8107 & 213 & 1948-1995 \\
\hline $\mathrm{CHA}$ & CHATTANOOGA & TN & 3502 & 8512 & 692 & 1948-1995 \\
\hline CHS & CHARLESTON & $\mathrm{SC}$ & 3254 & 8002 & 41 & $1945-1995$ \\
\hline CLT & CHARLOTTE & $\mathrm{NC}$ & 3513 & 8056 & 700 & 1948-1995 \\
\hline $\mathrm{CMH}$ & COLUMBUS & $\mathrm{OH}$ & 4000 & 8253 & 812 & 19481995 \\
\hline CRW & CHARLESTON & WV & 3822 & 8136 & 1015 & $1949-1995$ \\
\hline $\mathrm{CSG}$ & COLUMBUS & GA & 3231 & 8457 & 449 & 1948-1995 \\
\hline CVG & COVINGTON & KY & 3904 & 8440 & 869 & $1948-1995$ \\
\hline DAB & DAYTONA & FL & 2911 & 8103 & 29 & 1948-1995 \\
\hline EKN & ELKINS & WV & 3853 & 7951 & 1981 & $1948-1995$ \\
\hline EVV & EVANSVILLE & $\mathrm{IN}$ & 3803 & 8732 & 380 & $1948-1995$ \\
\hline EYW & KEY WEST & FL & 2433 & 8145 & 4 & 1948-1995 \\
\hline FMY & FORT MEYERS & FL & 2635 & 8152 & 15 & $1948-1995$ \\
\hline FSM* & FORT SMITH & $\mathrm{AR}$ & 3520 & 9422 & 449 & 1948-1995 \\
\hline GNV & GAINESVILLE & FL & 2941 & 8216 & 138 & $1984-1995$ \\
\hline GPT* & GULFPORT & MS & 3024 & 8904 & 30 & $1948-1993$ \\
\hline GSO & GREENSBORO & $\mathrm{NC}$ & 3605 & 7957 & 886 & $1948-1995$ \\
\hline HSV & HUNTSVILLE & $\mathrm{AL}$ & 3439 & 8646 & 624 & $1958-1995$ \\
\hline ILM & WILMINGTON & $\mathrm{NC}$ & 3416 & 7754 & 72 & 1948-1995 \\
\hline JAN* & JACKSON & MS & 3219 & 9005 & 330 & $1963-1995$ \\
\hline JAX & JACKSONVILLE & FL & 3030 & 8142 & 26 & 1948-1995 \\
\hline JKL & JACKSON & KY & 3736 & 8119 & 1355 & $1981-1995$ \\
\hline $\mathrm{LCH}^{*}$ & LAKE CHARLES & LA & 3007 & 9313 & 9 & 1961-1995 \\
\hline LEX & LEXINGTON & $\mathrm{KY}$ & 3102 & 8436 & 966 & $1948-1995$ \\
\hline LIT* $^{*}$ & LITTLE ROCK & AR & 3444 & 9214 & 257 & $1948-1995$ \\
\hline $\mathrm{MCN}$ & MACON & GA & 3242 & 8339 & 354 & $1948-1995$ \\
\hline $\mathrm{MCO}$ & ORLANDO & FL & 2826 & 8120 & 91 & $1974-1995$ \\
\hline MEI* & MERIDIAN & MS & 3220 & 8845 & 294 & $1948-1995$ \\
\hline MEM & MEMPHIS & $\mathrm{TN}$ & 3503 & 9000 & 265 & 1948-1995 \\
\hline MGM & MONTGOMERY & $\mathrm{AL}$ & 3218 & 8624 & 221 & $1948-1995$ \\
\hline MIA & MIAMI & FL & 2548 & 8018 & 12 & 1948-1995 \\
\hline MOB & MOBILE & $\mathrm{AL}$ & 3041 & 8815 & 211 & $1948-1995$ \\
\hline MSY* & NEW ORLEANS & LA & 2959 & 9015 & 4 & 1948-1995 \\
\hline ORF & NORFOLK & VA & 3654 & 7612 & 22 & 1948-1995 \\
\hline PAH & PADUCAH & KY & 3704 & 8846 & 410 & 1949-1995 \\
\hline PBI & WEST PALM & FL & 2641 & 8007 & 18 & 1948-1995 \\
\hline PNS & PENSACOLA & FL & 3028 & 8712 & 112 & $1948-1995$ \\
\hline RDU & RALEIGH-DURHAM & $\mathrm{NC}$ & 3552 & 7847 & 376 & $1950-1995$ \\
\hline RIC & RICHMOND & VA & 3730 & 7720 & 164 & 1948-1995 \\
\hline ROA & ROANOKE & VA & 3719 & 7998 & 1149 & 1948-1995 \\
\hline SAV & SAVANNAH & GA & 3208 & 8112 & 46 & $1950-1995$ \\
\hline SDF & LOUISVILLE & KY & 3811 & 8544 & 477 & $1948-1995$ \\
\hline $\mathrm{SHV}^{*}$ & SHREVEPORT & LA & 3228 & 9349 & 254 & 1948-1995 \\
\hline STL* & ST LOUIS & MO & 3845 & 9022 & 535 & $1945-1995$ \\
\hline TLH & TALLAHASSEE & FL & 3023 & 8422 & 55 & $1948-1995$ \\
\hline TPA & TAMPA & FL & 2758 & 8232 & 19 & 1948-1995 \\
\hline TRI & BRISTOL & $\mathrm{TN}$ & 3629 & 8224 & 1525 & $1948-1995$ \\
\hline TUP* & TUPELO & MS & 3416 & 8846 & 325 & 1983-1995 \\
\hline TYS & KNOXVILLE & $\mathrm{TN}$ & 3548 & 8400 & 949 & 19481995 \\
\hline VRB & VERO BEACH & FL & 2739 & 8025 & 23 & 1949-1995 \\
\hline
\end{tabular}


Table 2. Speed range and color-code for vector wind rose figures.

\begin{tabular}{cc}
\hline Speed range $($ knots $)$ & Color \\
\hline $0<$ Speed $\leq 3.5$ & Red \\
$3.5<$ Speed $\leq 6.5$ & Green \\
$6.5<$ Speed $\leq 10.5$ & Maroon \\
$10.5<$ Speed $\leq 16.5$ & Blue \\
$16.5<$ Speed $\leq 21.5$ & Black \\
\hline
\end{tabular}

Table 3. Southeastern U.S. sub-regions used for discussion of diurnal wind variations.

\begin{tabular}{ccl}
\hline Num & Sub-Region & \multicolumn{1}{c}{ Stations included } \\
\hline 1 & Southeast Coast & CHS, DAB, EYW, GNV, ILM, JAX, MCO, MIA, ORF, PBI, SAV, VRB \\
2 & Piedmont & AGS, AHN, ATL, CAE, CLT, CSG, GSO, MCN, MGM, RDU, RIC \\
3 & Appalachians & AVL, BHM, BNA, CHA, CRW, EKN, HSV, ROA, TRI, TYS \\
4 & Mississippi Valley & FSM, JAN, LIT, MEI, MEM, PAH, SHV, STL, TUP \\
5 & Ohio Valley & CHM, CVG, EVV, JKL, LEX, SDF \\
6 & Gulf Coast & AQQ, BTR, FMY, GPT, LCH, MOB, MSY, PNS, TLH, TPA \\
\hline
\end{tabular}


WSRC-TR-2004-00343

Vector Wind Velocity, Speed, and Mode Summaries for the Southeastern U.S. (U)

Table 4. Diurnal wind summaries for the vector average by sub-region of the Southeastern U. S. (16 compass points: N, NNE, ..., NNW; MX implies mixed results, SLB implies sea/land breeze, and CF implies winds

\begin{tabular}{ccccccccccccc}
\multicolumn{10}{c}{ following the coastal contour). } \\
\hline 01 LST & Jan & Feb & Mar & Apr & May & Jun & Jul & Aug & Sep & Oct & Nov & Dec \\
\hline East Coast & NW & WNW & WSW & SW & SSW & SSW & SW & SW & MX & N & NW & NW \\
Piedmont & W & WNW & W & SW & SSW & SSW & SSW & MX & NE & N & WNW & WNW \\
Appalachians & WNW & NW & W & MX & MX & MX & MX & MX & MX & MX & MX & NW \\
Miss. Val. & MX & MX & S & S & SSE & SSE & S & SE & ESE & MX & MX & MX \\
Ohio Val. & W & WNW & W & SW & S & S & S & SSE & SE & MX & SW & WSW \\
Gulf Coast & NNE & NE & SE & SE & SSE & SE & MX & MX & ENE & NE & NE & ENE \\
\hline
\end{tabular}

\begin{tabular}{|c|c|c|c|c|c|c|c|c|c|c|c|c|}
\hline 04 LST & Jan & Feb & Mar & Apr & May & Jun & Jul & Aug & Sep & Oct & Nov & Dec \\
\hline East Coast & NW & NW & $\mathrm{W}$ & $\mathrm{W}$ & WSW & SW & SW & MX & MX & $\mathrm{N}$ & NNW & NW \\
\hline Piedmont & NW & WNW & W & WSW & MX & MX & SW & MX & NNE & $\mathrm{N}$ & NW & WNW \\
\hline Appalachians & NW & NW & WNW & MX & MX & MX & MX & MX & MX & MX & NW & NW \\
\hline Miss. Val. & MX & MX & MX & $\mathrm{S}$ & SSE & SSE & $\mathrm{S}$ & SSE & MX & MX & MX & MX \\
\hline Ohio Val. & WSW & WNW & W & SW & $\mathrm{S}$ & SSW & SSW & MX & MX & MX & SW & WSW \\
\hline Gulf Coast & NNE & NNE & MX & MX & MX & MX & MX & MX & $\mathrm{NE}$ & $\mathrm{NE}$ & $\mathrm{NE}$ & NE \\
\hline 07 LST & Jan & Feb & Mar & Apr & May & Jun & Jul & Aug & Sep & Oct & Nov & Dec \\
\hline East Coast & NW & NW & WNW & $\mathrm{W}$ & MX & $\mathrm{W}$ & WSW & MX & MX & $\mathrm{N}$ & NW & NW \\
\hline Piedmont & WNW & NW & WNW & W & MX & MX & SW & MX & NNE & $\mathrm{N}$ & NW & WNW \\
\hline Appalachians & NW & NW & NW & MX & MX & MX & MX & MX & MX & NNE & NW & NW \\
\hline Miss. Val. & MX & MX & MX & $\mathrm{S}$ & SSE & $\mathrm{S}$ & $\mathrm{S}$ & SSW & $\mathrm{E}$ & MX & MX & MX \\
\hline Ohio Val. & W & WNW & W & SW & $\mathrm{S}$ & $\mathrm{S}$ & SSW & SSE & MX & MX & SW & WSW \\
\hline Gulf Coast & NNE & NNE & ENE & $\mathrm{E}$ & $\mathrm{E}$ & MX & MX & $\mathrm{NE}$ & $\mathrm{NE}$ & $\mathrm{NE}$ & $\mathrm{NE}$ & NE \\
\hline 10 LST & Jan & Feb & Mar & Apr & May & Jun & Jul & Aug & Sep & Oct & Nov & Dec \\
\hline East Coast & NW & NW & WNW & $\mathrm{W}$ & MX & MX & MX & MX & $\mathrm{NE}$ & NNE & MX & MX \\
\hline Piedmont & NW & NW & WNW & W & $\mathrm{W}$ & $\mathrm{W}$ & SW & NNE & $\mathrm{NE}$ & NNE & NNW & NW \\
\hline Appalachians & NW & NW & W & W & MX & MX & MX & MX & MX & $\mathrm{MX}$ & NW & NW \\
\hline Miss. Val. & MX & MX & $\mathrm{S}$ & SSW & $\mathrm{S}$ & SW & SW & MX & E & MX & MX & MX \\
\hline Ohio Val. & WSW & WSW & SW & SW & SW & SW & SW & SW & SSW & SW & SW & SW \\
\hline Gulf Coast & $\mathrm{NE}$ & $\mathrm{NE}$ & $\mathrm{E}$ & SE & SE & SSE & MX & MX & ENE & ENE & ENE & ENE \\
\hline 13 LST & Jan & Feb & Mar & Apr & May & Jun & Jul & Aug & Sep & Oct & Nov & Dec \\
\hline East Coast & NW & MX & MX & MX & MX & SLB & SLB & SLB & ENE & $\mathrm{NE}$ & MX & MX \\
\hline Piedmont & W & W & W & WSW & WSW & WSW & SW & MX & NE & NNE & W & W \\
\hline Appalachians & W & W & WSW & WSW & W & W & W & W & MX & NW & W & W \\
\hline Miss. Val. & W & W & SW & S & S & $\mathrm{S}$ & WSW & MX & MX & MX & MX & MX \\
\hline Ohio Val. & WSW & WSW & WSW & WSW & WSW & SW & WSW & WSW & WSW & WSW & WSW & WSW \\
\hline Gulf Coast & NE & MX & SLB & SLB & SLB & SLB & SLB & SLB & ESE & ENE & ENE & ENE \\
\hline 16 LST & Jan & Feb & Mar & Apr & May & Jun & Jul & Aug & Sep & Oct & Nov & Dec \\
\hline East Coast & MX & MX & MX & SLB & SLB & SLB & SLB & SLB & SLB & $\mathrm{NE}$ & MX & MX \\
\hline Piedmont & W & W & W & WSW & WSW & MX & SW & $\mathrm{MX}$ & $\mathrm{NE}$ & NNE & W & W \\
\hline Appalachians & W & W & WSW & WSW & W & W & WSW & WNW & MX & MX & W & W \\
\hline Miss. Val. & WNW & WNW & WSW & SSW & S & $\mathrm{S}$ & SW & MX & $\mathrm{NE}$ & MX & MX & $\mathrm{MX}$ \\
\hline Ohio Val. & WSW & W & WSW & WSW & WSW & WSW & WSW & W & WSW & WSW & WSW & WSW \\
\hline Gulf Coast & MX & MX & SLB & SLB & SLB & SLB & SLB & SLB & MX & MX & MX & MX \\
\hline
\end{tabular}

\begin{tabular}{|c|c|c|c|c|c|c|c|c|c|c|c|c|}
\hline 19 LST & Jan & Feb & Mar & Apr & May & Jun & Jul & Aug & Sep & Oct & Nov & Dec \\
\hline East Coast & MX & MX & MX & SLB & SLB & SLB & SLB & SLB & SLB & $\mathrm{NE}$ & MX & MX \\
\hline Piedmont & W & W & WSW & SW & $\mathrm{S}$ & SSE & $\mathrm{S}$ & $\mathrm{SE}$ & ESE & NNE & NW & NW \\
\hline Appalachians & WNW & WNW & W & WSW & W & W & WSW & MX & MX & NNW & NW & WNW \\
\hline Miss. Val. & MX & $\mathrm{N}$ & MX & $\mathrm{S}$ & SSE & SSE & $\mathrm{S}$ & MX & ENE & E & ESE & E \\
\hline Ohio Val. & WSW & W & W & WSW & WSW & SW & SW & MX & MX & MX & SW & WSW \\
\hline Gulf Coast & MX & MX & SLB & SLB & SLB & SLB & SLB & SLB & $\mathrm{NE}$ & $\mathrm{NE}$ & $\mathrm{NE}$ & MX \\
\hline 22 LST & Jan & Feb & Mar & Apr & May & Jun & Jul & Aug & Sep & Oct & Nov & Dec \\
\hline East Coast & MX & MX & $\mathrm{CF}$ & $\mathrm{CF}$ & $\mathrm{CF}$ & $\mathrm{CF}$ & $\mathrm{CF}$ & MX & $\mathrm{NE}$ & NNE & MX & MX \\
\hline Piedmont & W & W & WSW & SSW & $\mathrm{S}$ & SSE & $\mathrm{S}$ & SE & ENE & $\mathrm{NE}$ & WNW & WNW \\
\hline Appalachians & WNW & NW & W & WSW & MX & MX & MX & MX & $\mathrm{NE}$ & $\mathrm{N}$ & WNW & WNW \\
\hline Miss. Val. & MX & $\mathrm{E}$ & SSE & SSE & SE & SE & SSE & $\mathrm{SE}$ & E & E & ESE & ESE \\
\hline Ohio Val. & WSW & W & MX & SW & $\mathrm{S}$ & $\mathrm{S}$ & $\mathrm{S}$ & MX & MX & MX & SW & WSW \\
\hline Gulf Coast & NE & MX & MX & MX & MX & MX & MX & MX & ENE & $\mathrm{NE}$ & $\mathrm{NE}$ & $\mathrm{NE}$ \\
\hline
\end{tabular}


Table 5. Diurnal wind summaries for the mode by sub-region of the Southeastern U.S. (16 compass points, N, $\mathrm{NNE}, \ldots \mathrm{NNW} ; \mathrm{MX}=$ mixed results, $\mathrm{SLB}=$ sea/land breeze; and $\mathrm{CF}=$ winds following the coastal contour).

\begin{tabular}{|c|c|c|c|c|c|c|c|c|c|c|c|c|}
\hline $01 \mathrm{LST}$ & Jan & Feb & Mar & Apr & May & Jun & Jul & Aug & Sep & Oct & Nov & Dec \\
\hline East Coast & MX & MX & MX & MX & SW & SW & SW & SW & MX & NNE & $\mathrm{CF}$ & NW \\
\hline Piedmont & MX & MX & MX & MX & MX & MX & SSW & MX & MX & MX & MX & MX \\
\hline Appalachians & MX & MX & MX & MX & MX & MX & MX & MX & MX & MX & MX & MX \\
\hline Miss. Val. & MX & MX & MX & $\mathrm{S}$ & $\mathrm{S}$ & $\mathrm{S}$ & $\mathrm{S}$ & MX & MX & MX & $\mathrm{S}$ & $\mathrm{S}$ \\
\hline Ohio Val. & MX & MX & MX & MX & MX & $\mathrm{S}$ & SSW & MX & MX & MX & MX & MX \\
\hline Gulf Coast & SLB & SLB & MX & MX & MX & MX & $\mathrm{MX}$ & MX & MX & $\mathrm{NE}$ & SLB & SLB \\
\hline 04 LST & Jan & Feb & Mar & Apr & May & Jun & Jul & Aug & Sep & Oct & Nov & Dec \\
\hline East Coast & MX & MX & MX & SW & SW & SW & SW & MX & MX & NNE & $\mathrm{CF}$ & MX \\
\hline Piedmont & MX & MX & MX & MX & MX & MX & SW & MX & $\mathrm{NE}$ & $\mathrm{NE}$ & MX & MX \\
\hline Appalachians & MX & MX & MX & MX & MX & MX & MX & MX & $\mathrm{NE}$ & MX & MX & MX \\
\hline Miss. Val. & MX & MX & $\mathrm{S}$ & $\mathrm{S}$ & $\mathrm{S}$ & $\mathrm{S}$ & SSW & MX & MX & MX & MX & $\mathrm{S}$ \\
\hline Ohio Val. & MX & MX & MX & MX & MX & $\mathrm{S}$ & SSW & MX & MX & MX & MX & MX \\
\hline Gulf Coast & SLB & SLB & MX & MX & MX & MX & MX & MX & $\mathrm{NE}$ & $\mathrm{NE}$ & SLB & SLB \\
\hline 07 LST & Jan & Feb & Mar & Apr & May & Jun & Jul & Aug & Sep & Oct & Nov & Dec \\
\hline East Coast & MX & MX & MX & SW & WSW & WSW & WSW & MX & MX & $\mathrm{CF}$ & $\mathrm{CF}$ & MX \\
\hline Piedmont & MX & MX & MX & MX & MX & MX & SW & MX & $\mathrm{NE}$ & $\mathrm{NE}$ & MX & MX \\
\hline Appalachians & MX & MX & MX & MX & MX & MX & MX & MX & MX & MX & MX & MX \\
\hline Miss. Val. & $\mathrm{N}$ & MX & MX & $\mathrm{S}$ & MX & $\mathrm{S}$ & SSW & MX & MX & MX & $\mathrm{S}$ & $\mathrm{S}$ \\
\hline Ohio Val. & MX & MX & MX & MX & $\mathrm{S}$ & $\mathrm{S}$ & SSW & MX & MX & MX & $\mathrm{S}$ & $\mathrm{S}$ \\
\hline Gulf Coast & SLB & SLB & MX & MX & MX & MX & MX & MX & $\mathrm{NE}$ & $\mathrm{NE}$ & $\mathrm{NE}$ & MX \\
\hline 10 LST & Jan & Feb & Mar & Apr & May & Jun & Jul & Aug & Sep & Oct & Nov & Dec \\
\hline East Coast & MX & $\mathrm{CF}$ & MX & MX & MX & MX & MX & MX & $\mathrm{NE}$ & $\mathrm{NE}$ & $\mathrm{CF}$ & $\mathrm{CF}$ \\
\hline Piedmont & MX & MX & MX & MX & MX & SW & SW & MX & $\mathrm{NE}$ & $\mathrm{NE}$ & MX & MX \\
\hline Appalachians & MX & MX & MX & MX & MX & MX & MX & MX & MX & MX & MX & MX \\
\hline Miss. Val. & MX & MX & $\mathrm{S}$ & $\mathrm{S}$ & $\mathrm{S}$ & SSW & MX & MX & MX & MX & $\mathrm{S}$ & $\mathrm{S}$ \\
\hline Ohio Val. & MX & MX & SSW & SSW & SW & SW & SW & SW & MX & SSW & SSW & SSW \\
\hline Gulf Coast & MX & MX & $\mathrm{MX}$ & MX & MX & MX & MX & MX & ENE & ENE & MX & MX \\
\hline 13 LST & Jan & Feb & Mar & Apr & May & Jun & Jul & Aug & Sep & Oct & Nov & Dec \\
\hline East Coast & MX & MX & MX & MX & MX & SLB & MX & SLB & ENE & $\mathrm{NE}$ & MX & MX \\
\hline Piedmont & MX & MX & MX & MX & SW & SW & SW & MX & $\mathrm{NE}$ & $\mathrm{NE}$ & MX & MX \\
\hline Appalachians & MX & MX & MX & MX & MX & MX & MX & MX & MX & MX & MX & MX \\
\hline Miss. Val. & MX & MX & $\mathrm{S}$ & $\mathrm{S}$ & $\mathrm{S}$ & SSW & SSW & MX & MX & MX & MX & MX \\
\hline Ohio Val. & MX & MX & MX & SW & SW & SW & SW & SW & SW & SW & SW & SW \\
\hline Gulf Coast & MX & MX & SLB & SLB & SLB & SLB & MX & MX & MX & MX & MX & MX \\
\hline 16 LST & Jan & Feb & Mar & Apr & May & Jun & Jul & Aug & Sep & Oct & Nov & Dec \\
\hline East Coast & MX & MX & MX & SLB & SLB & SLB & SLB & SLB & SLB & MX & MX & MX \\
\hline Piedmont & MX & MX & MX & MX & MX & MX & MX & MX & $\mathrm{NE}$ & $\mathrm{NE}$ & MX & MX \\
\hline Appalachians & MX & MX & MX & MX & MX & W & MX & MX & MX & MX & MX & MX \\
\hline Miss. Val. & MX & MX & MX & $\mathrm{S}$ & $\mathrm{S}$ & $\mathrm{S}$ & MX & MX & $\mathrm{N}$ & MX & MX & $\mathrm{S}$ \\
\hline Ohio Val. & MX & MX & MX & WSW & SW & SW & SW & SW & MX & MX & MX & MX \\
\hline Gulf Coast & MX & MX & SLB & SLB & SLB & SLB & SLB & SLB & SLB & MX & MX & MX \\
\hline 19 LST & Jan & Feb & Mar & Apr & May & Jun & Jul & Aug & Sep & Oct & Nov & Dec \\
\hline East Coast & MX & $\mathrm{CF}$ & $\mathrm{CF}$ & SLB & SLB & SLB & SLB & SLB & SLB & $\mathrm{NE}$ & MX & MX \\
\hline Piedmont & MX & MX & MX & MX & MX & MX & MX & MX & $\mathrm{NE}$ & $\mathrm{NE}$ & MX & MX \\
\hline Appalachians & MX & MX & MX & MX & MX & MX & MX & MX & MX & MX & MX & MX \\
\hline Miss. Val. & MX & MX & MX & $\mathrm{S}$ & SSE & SSE & $\mathrm{S}$ & MX & $\mathrm{N}$ & MX & MX & MX \\
\hline Ohio Val. & MX & MX & MX & MX & SSW & SW & SW & MX & MX & MX & MX & MX \\
\hline Gulf Coast & MX & MX & SLB & SLB & SLB & SLB & SLB & MX & MX & MX & MX & MX \\
\hline 22 LST & Jan & Feb & Mar & Apr & May & Jun & Jul & Aug & Sep & Oct & Nov & Dec \\
\hline East Coast & MX & $\mathrm{MX}$ & MX & $\mathrm{CF}$ & $\mathrm{CF}$ & $\mathrm{CF}$ & $\mathrm{CF}$ & MX & $\mathrm{NE}$ & NNE & MX & MX \\
\hline Piedmont & MX & MX & MX & MX & MX & MX & MX & MX & MX & MX & MX & MX \\
\hline Appalachians & MX & MX & MX & MX & MX & MX & MX & MX & MX & MX & MX & MX \\
\hline Miss. Val. & MX & MX & $\mathrm{S}$ & $\mathrm{S}$ & $\mathrm{S}$ & $\mathrm{S}$ & $\mathrm{S}$ & MX & MX & MX & $\mathrm{S}$ & $\mathrm{S}$ \\
\hline Ohio Val. & MX & MX & MX & MX & $\mathrm{S}$ & $\mathrm{S}$ & $\mathrm{S}$ & MX & $\mathrm{S}$ & $\mathrm{S}$ & $\mathrm{S}$ & $\mathrm{S}$ \\
\hline Gulf Coast & SLB & MX & MX & MX & MX & MX & MX & MX & MX & MX & MX & SLB \\
\hline
\end{tabular}




\section{List of Figures}

1. Sample plot showing average wind vector at each station for the month of April and a local time of 16:00. Averages are obtained for each station over the period of record given in Table 1 .

2. Sample plot showing the mode at each station for the month of April and a local time of 16:00. Modes are obtained for each station over the period of record given in Table 1.

3. Sub-regions of the Southeastern U.S. for the purpose of discussion.

4. Variation of vector averages with month and time of day for the East Coast subregion.

5. Variation of mode with month and time of day for the East Coast sub-region.

6. Variation of vector averages with month and time of day for the Piedmont subregion.

7. Variation of mode with month and time of day for the Piedmont sub-region.

8. Variation of vector averages with month and time of day for the Appalachian subregion.

9. Variation of mode with month and time of day for the Appalachian sub-region.

10. Variation of vector averages with month and time of day for the Mississippi Valley sub-region.

11. Variation of mode with month and time of day for the Mississippi Valley subregion.

12. Variation of vector averages with month and time of day for the Ohio Valley subregion.

13. Variation of mode with month and time of day for the Ohio Valley sub-region.

14. Variation of vector averages with month and time of day for the Gulf Coast subregion.

15. Variation of mode with month and time of day for the Gulf Coast sub-region. 


\section{April Time: 16 EST}

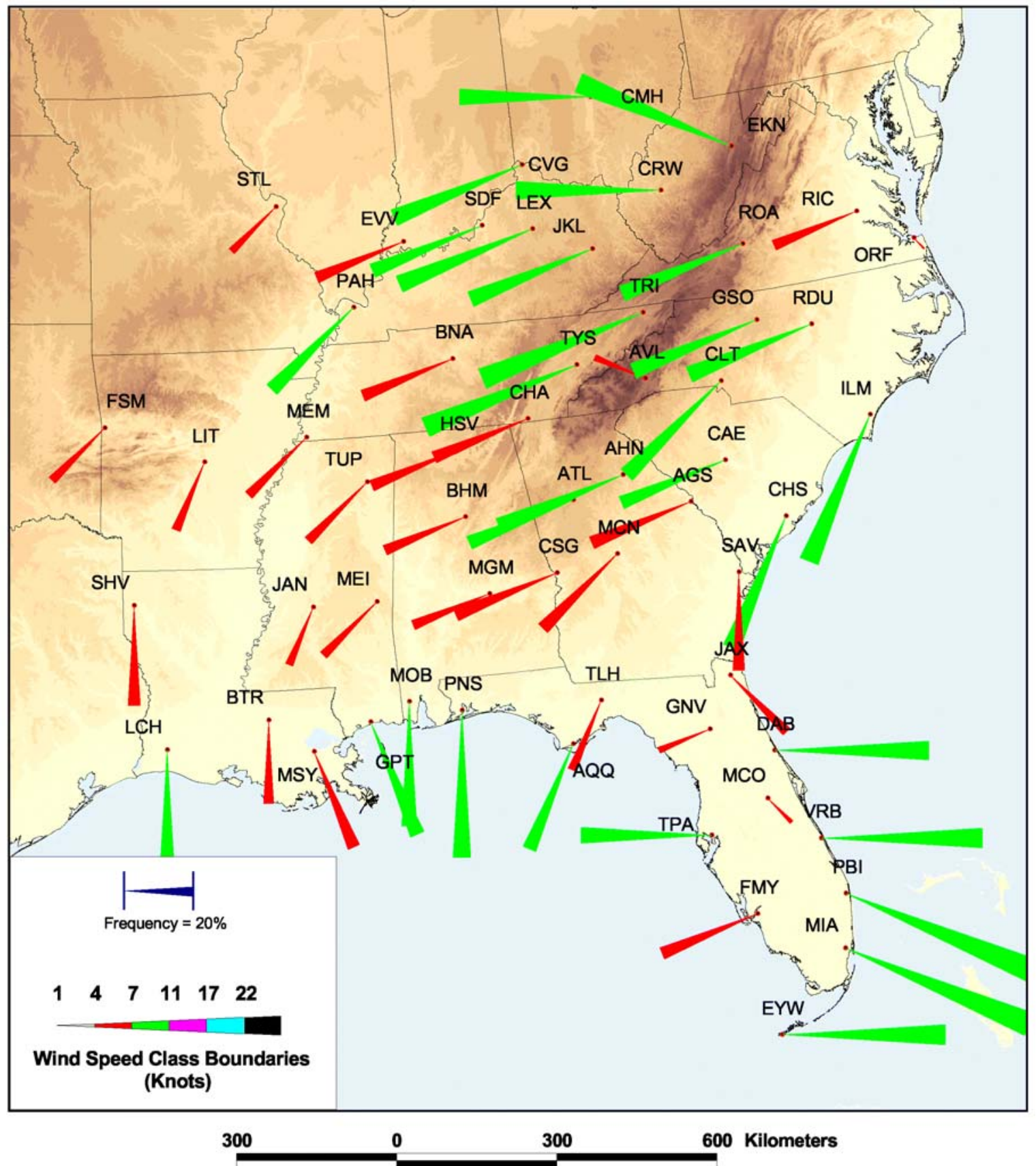

Figure 1: Sample plot showing average wind vector at each station for the month of April and a local time of 16:00. Averages are obtained for each station over the period of record given in Table 1. 


\section{April Time: 16 EST}

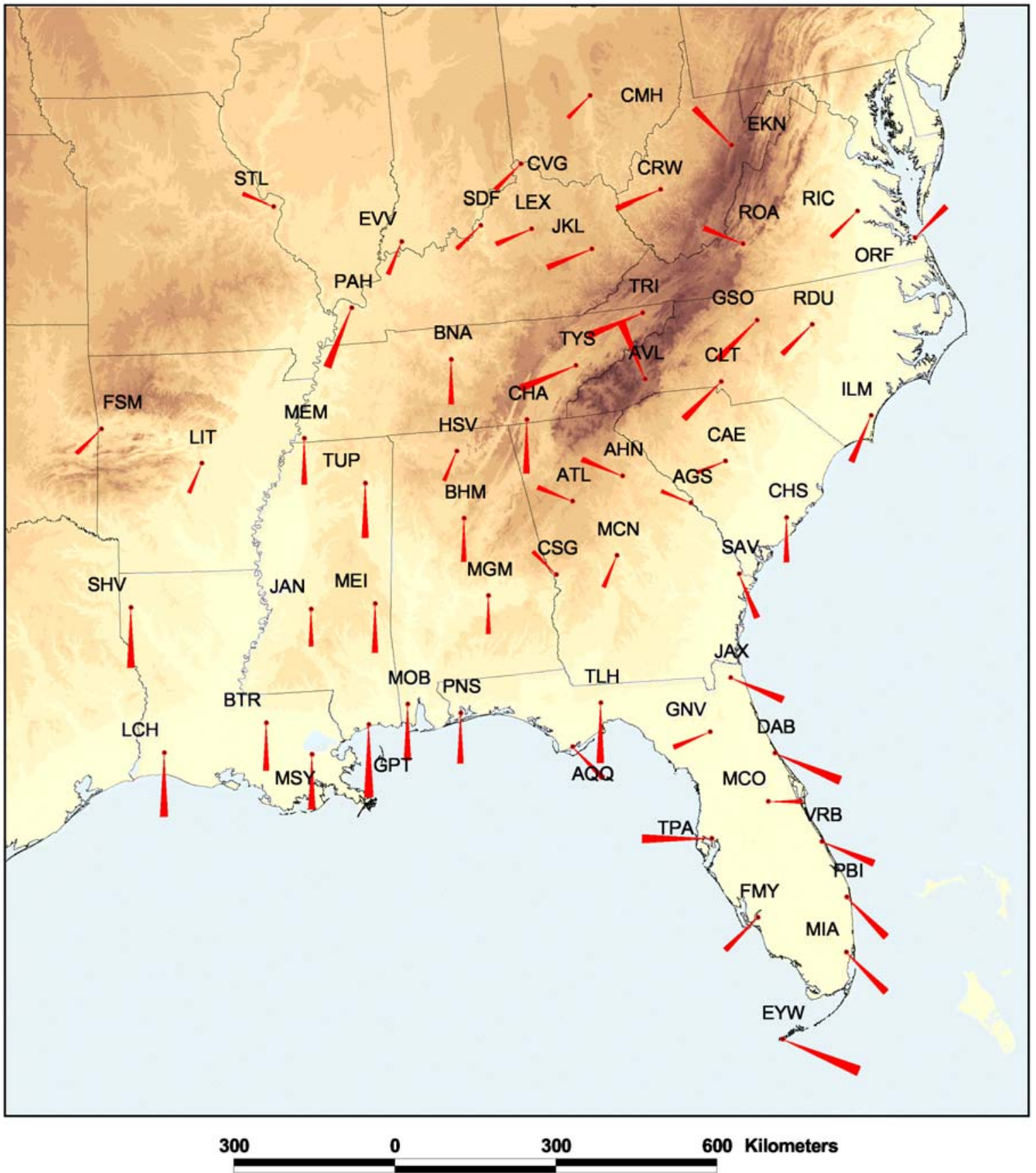

Figure 2: Sample plot showing the mode at each station for the month of April and a local time of 16:00. Modes are obtained for each station over the period of record given in Table 1. 


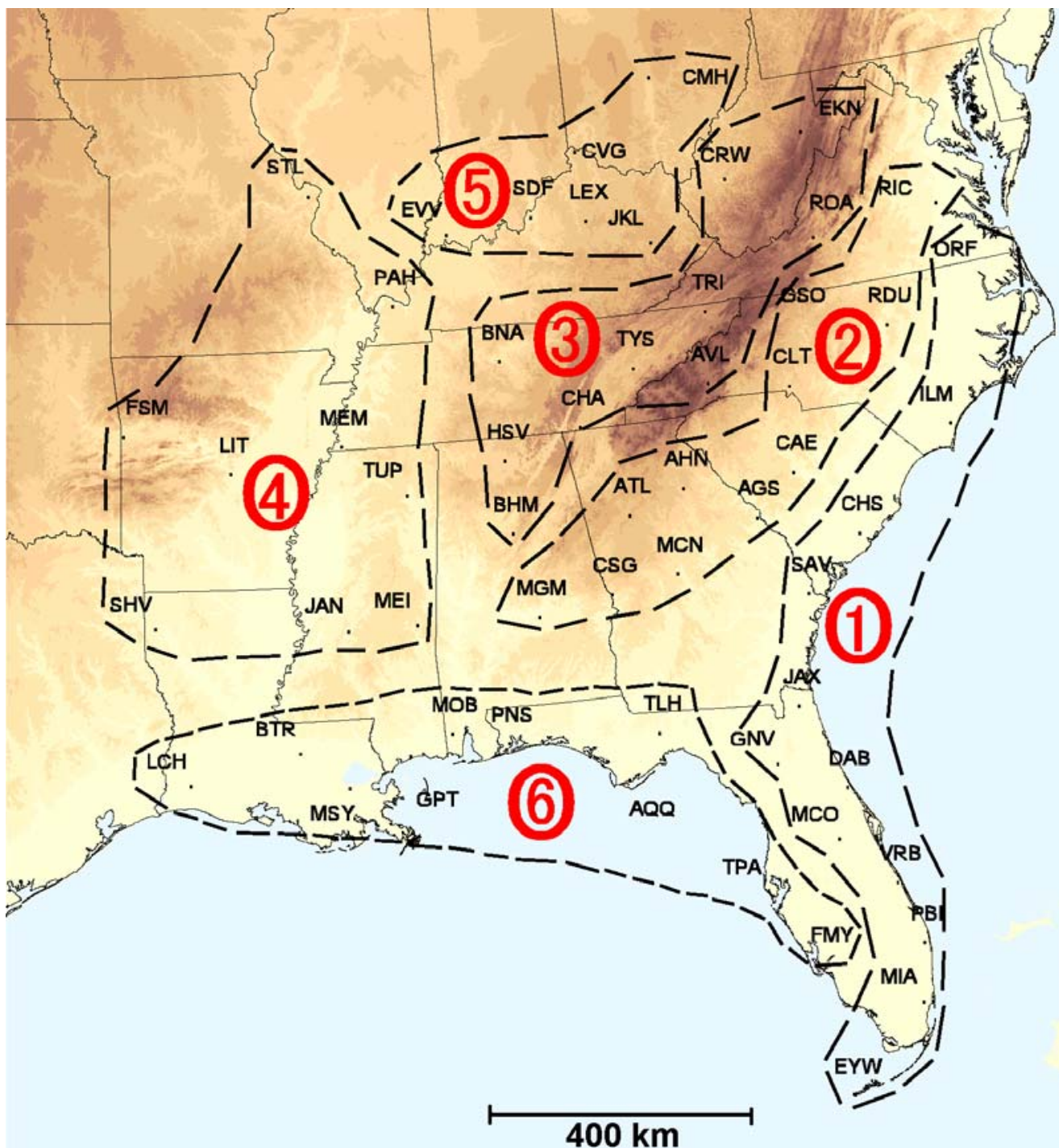

Figure 3: Sub-regions of the Southeastern U.S. for the purpose of discussion. 


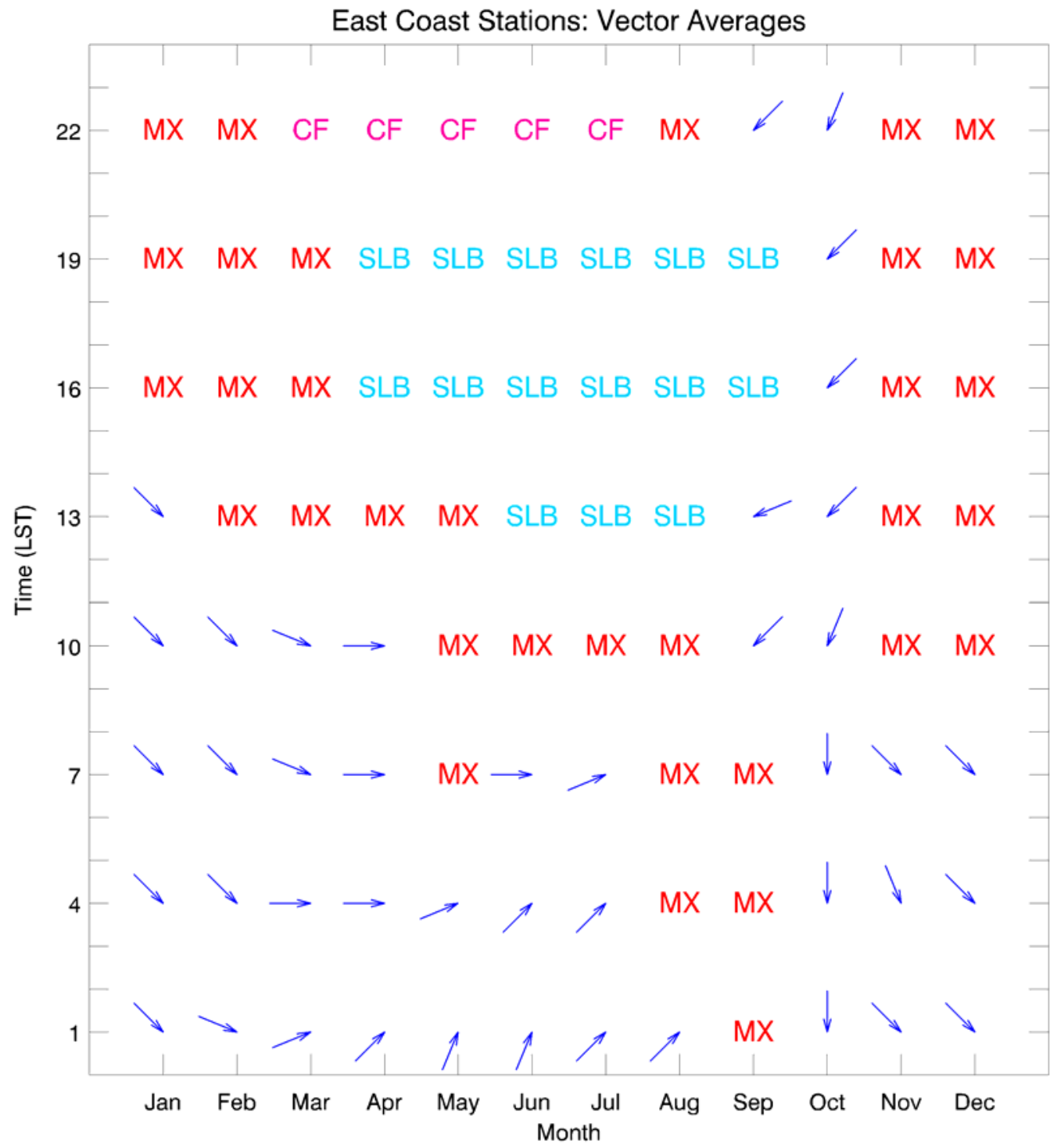

Figure 4: Variation of vector averages with month and time of day for the East Coast sub-region. 


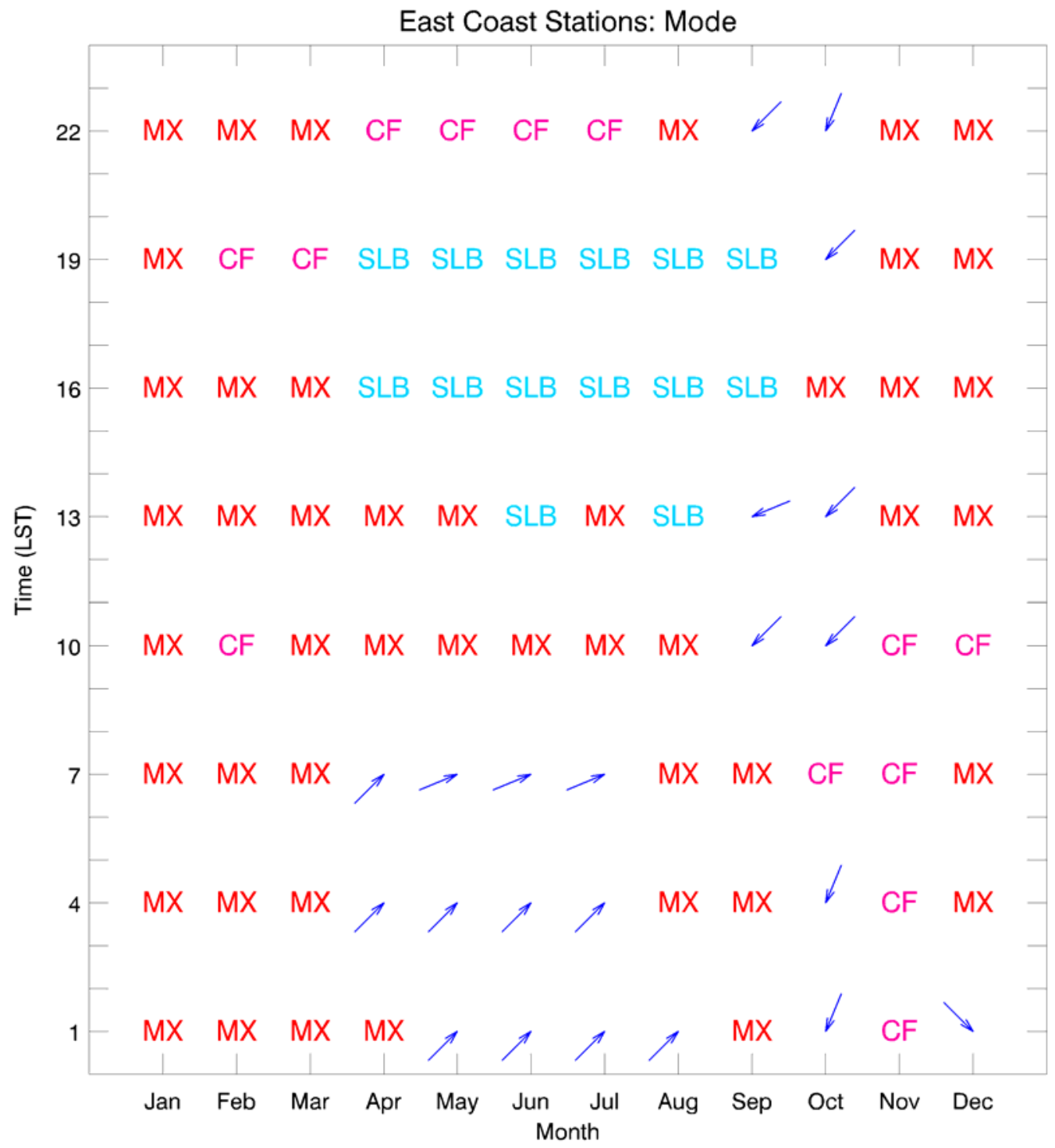

Figure 5: Variation of mode with month and time of day for the East Coast sub-region. 


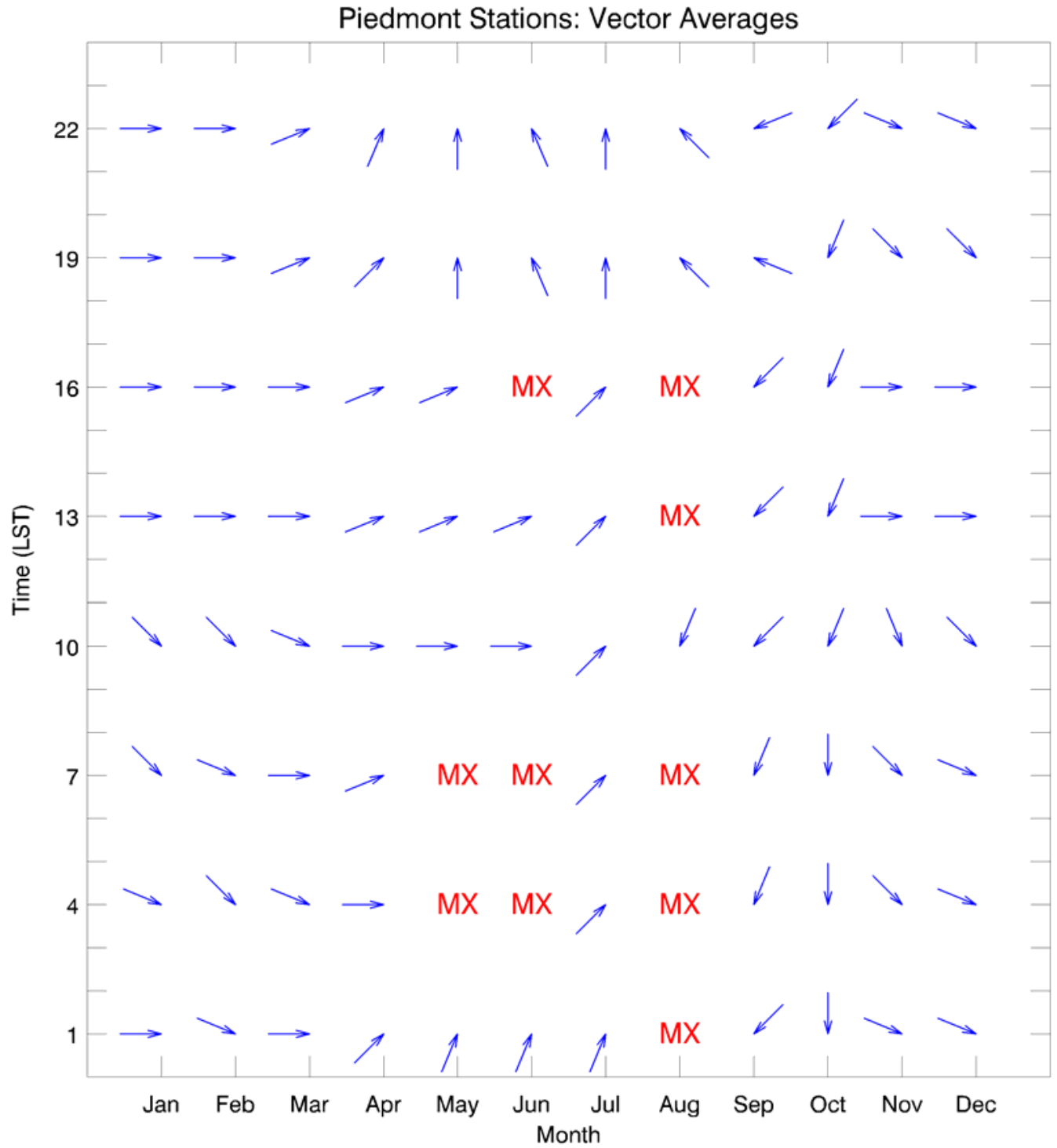

Figure 6: Variation of vector averages with month and time of day for the Piedmont sub-region. 


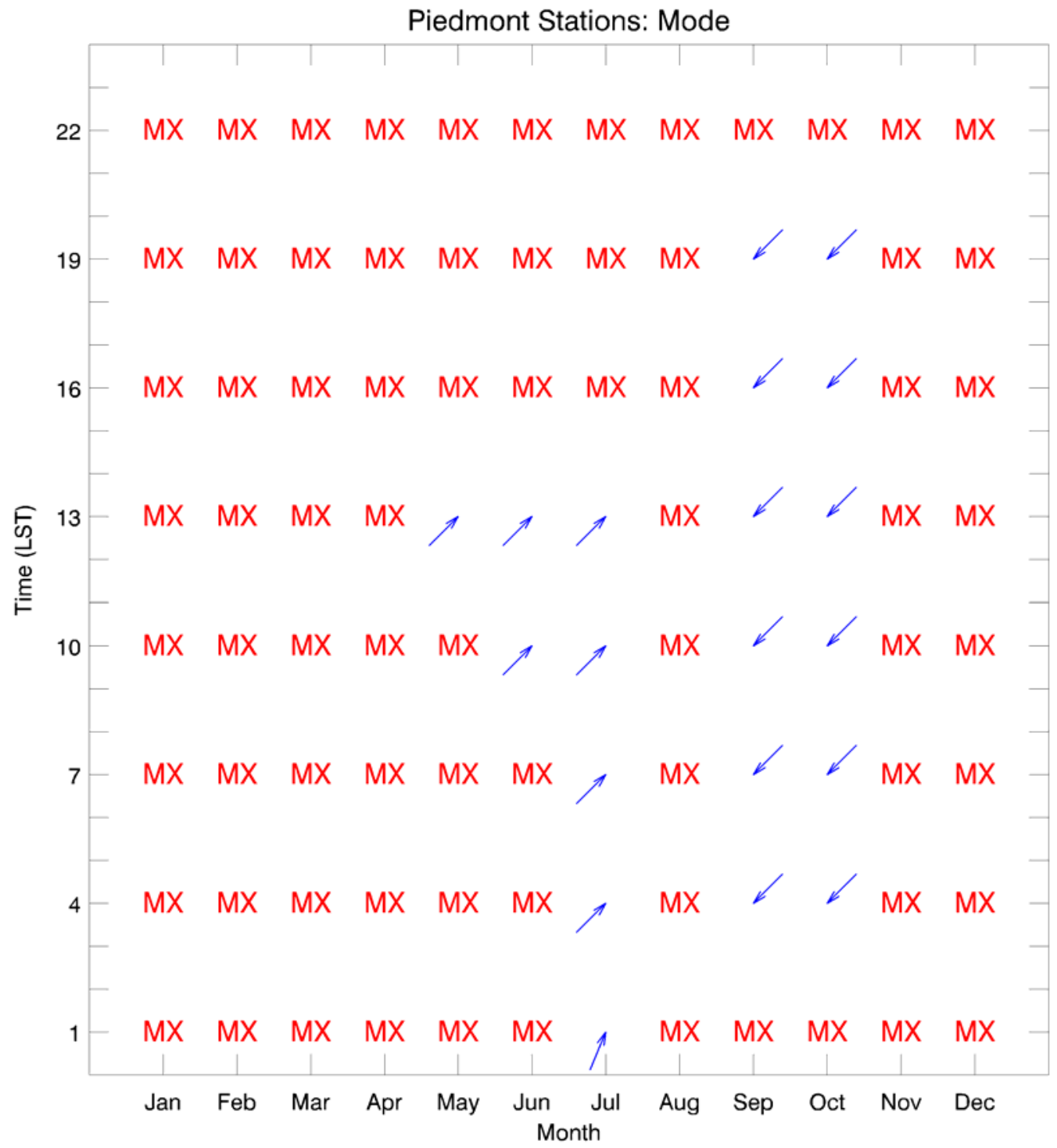

Figure 7: Variation of mode with month and time of day for the Piedmont sub-region. 


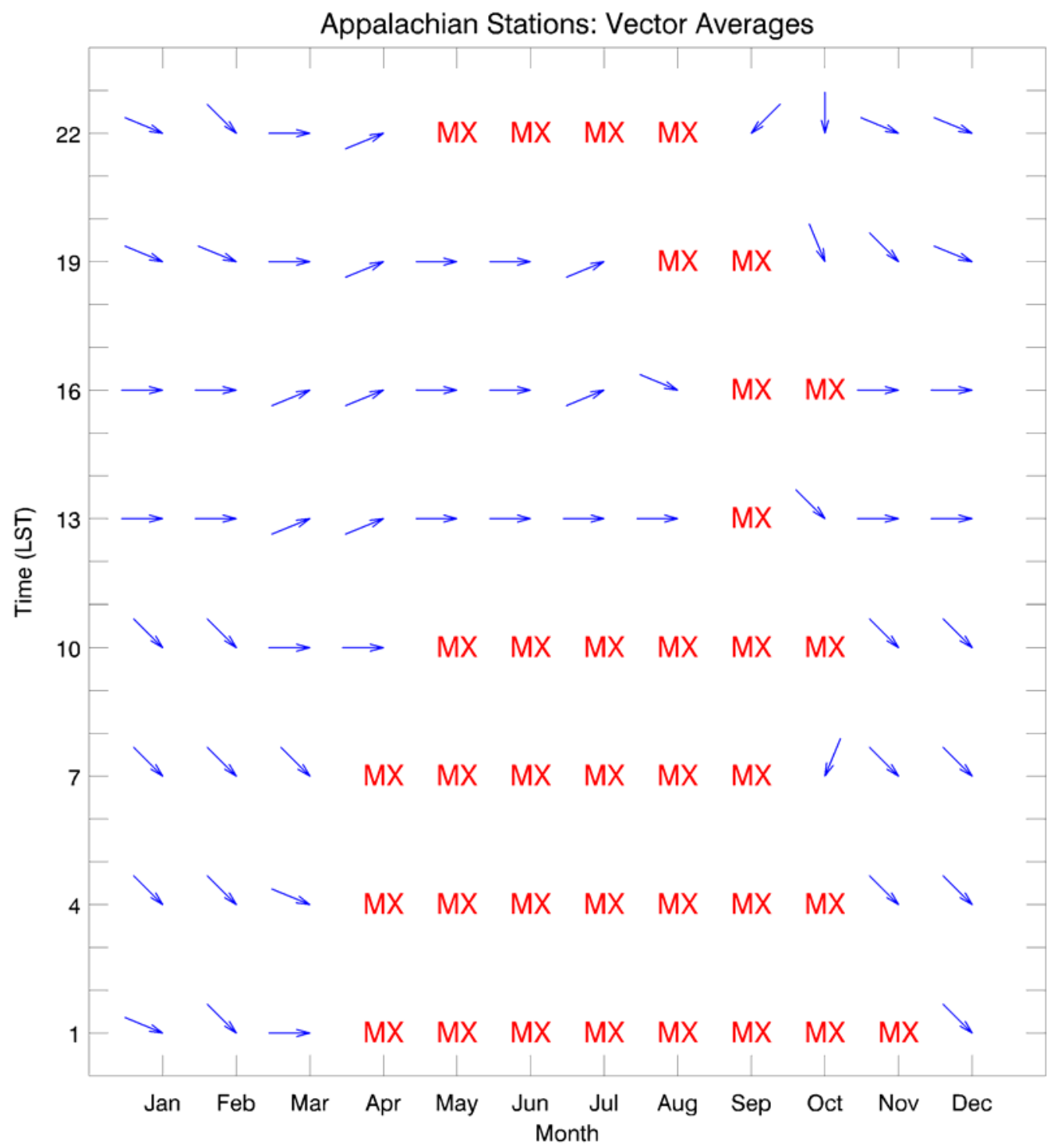

Figure 8: Variation of vector averages with month and time of day for the Appalachian sub-region. 


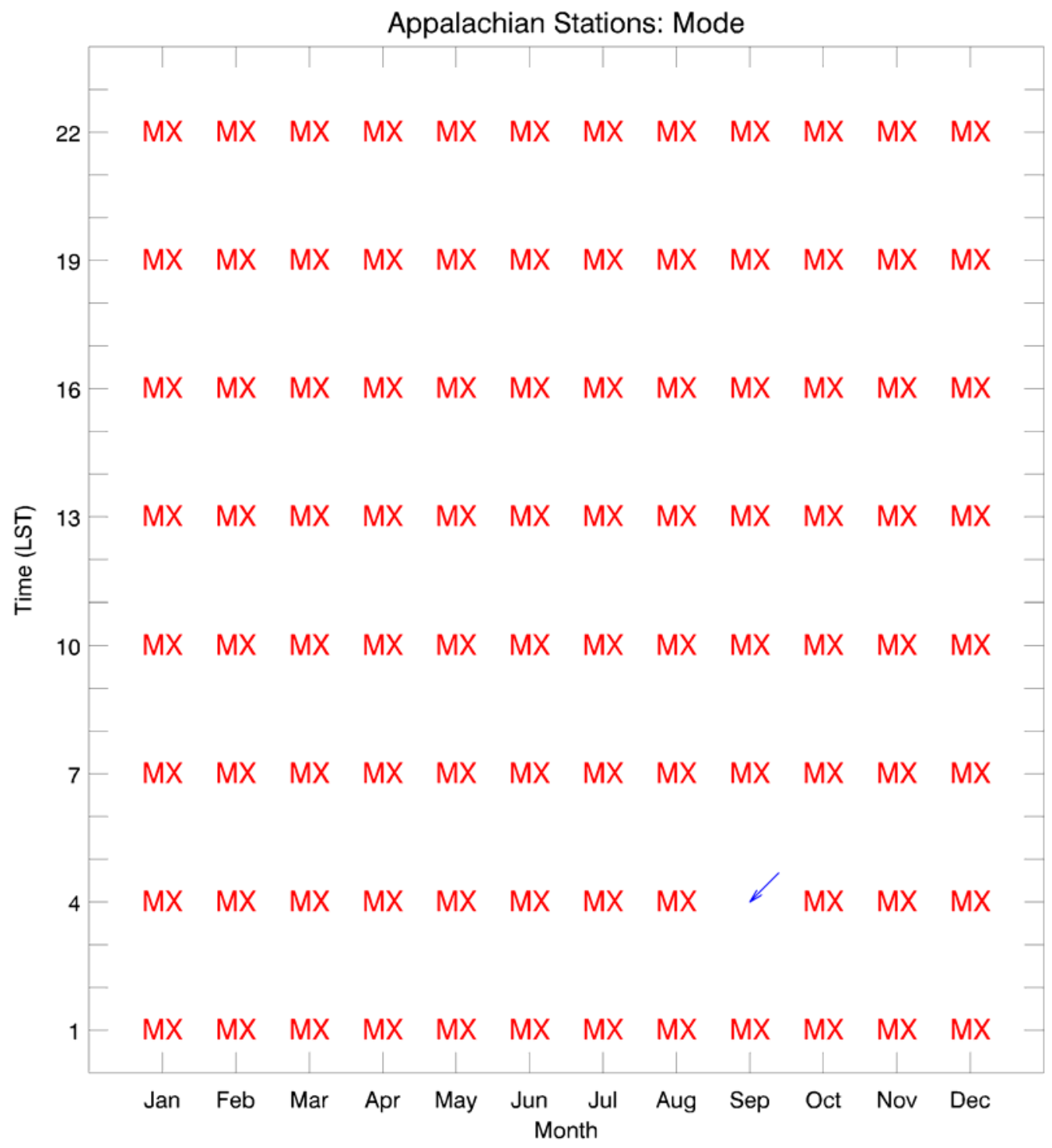

Figure 9: Variation of mode with month and time of day for the Appalachian sub-region. 


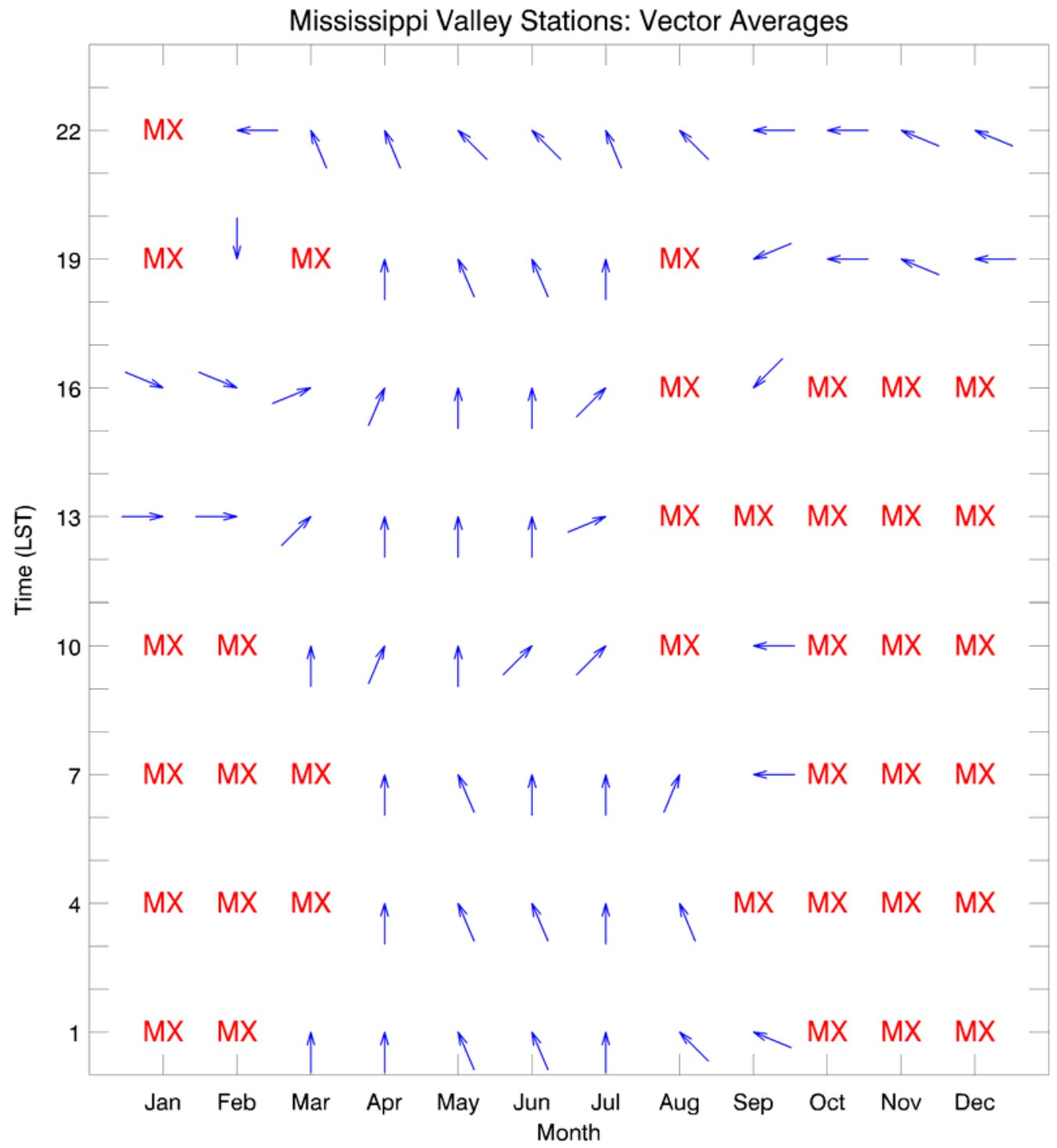

Figure 10: Variation of vector averages with month and time of day for the Mississippi Valley sub-region. 


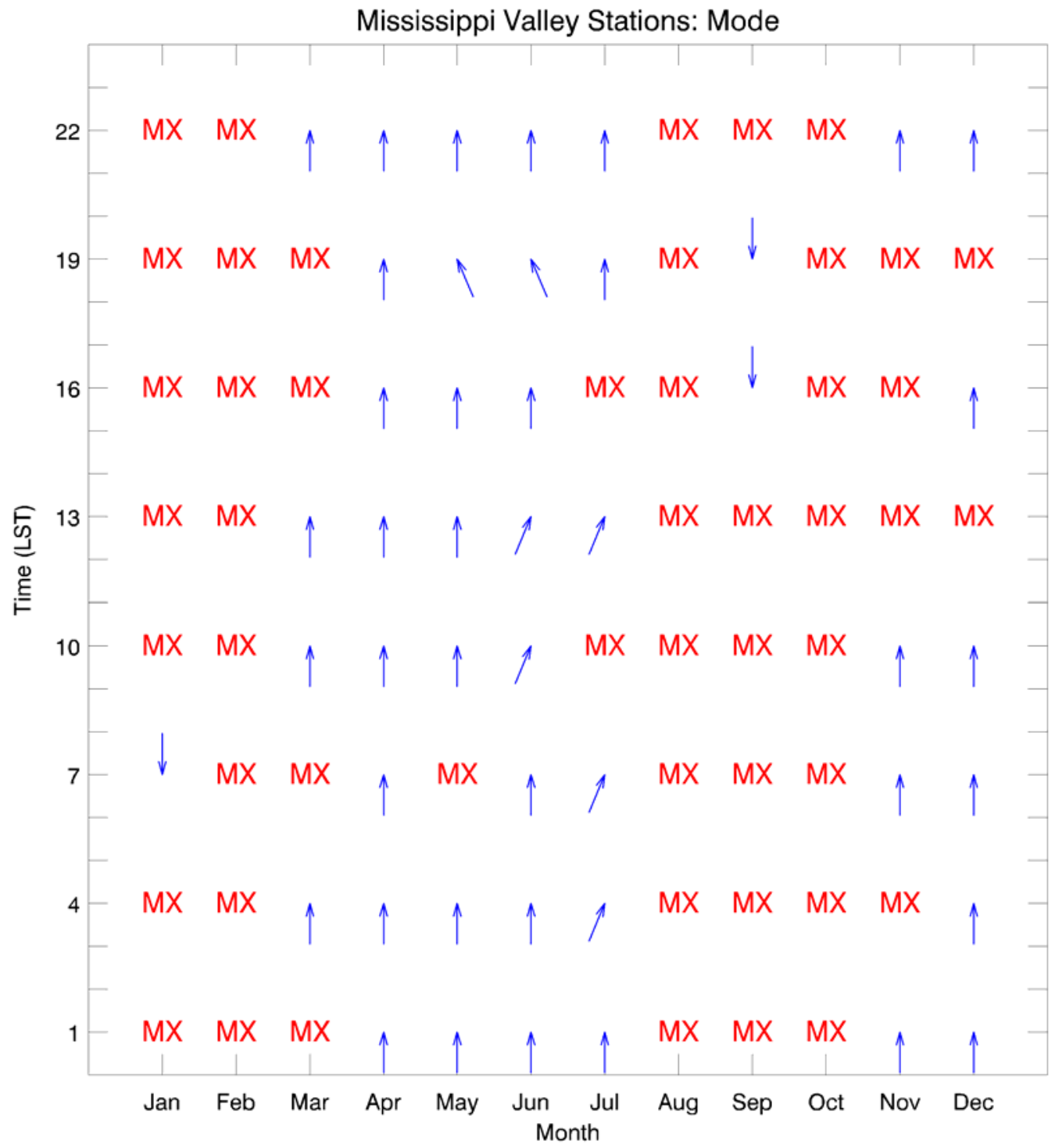

Figure 11: Variation of mode with month and time of day for the Mississippi Valley sub-region. 


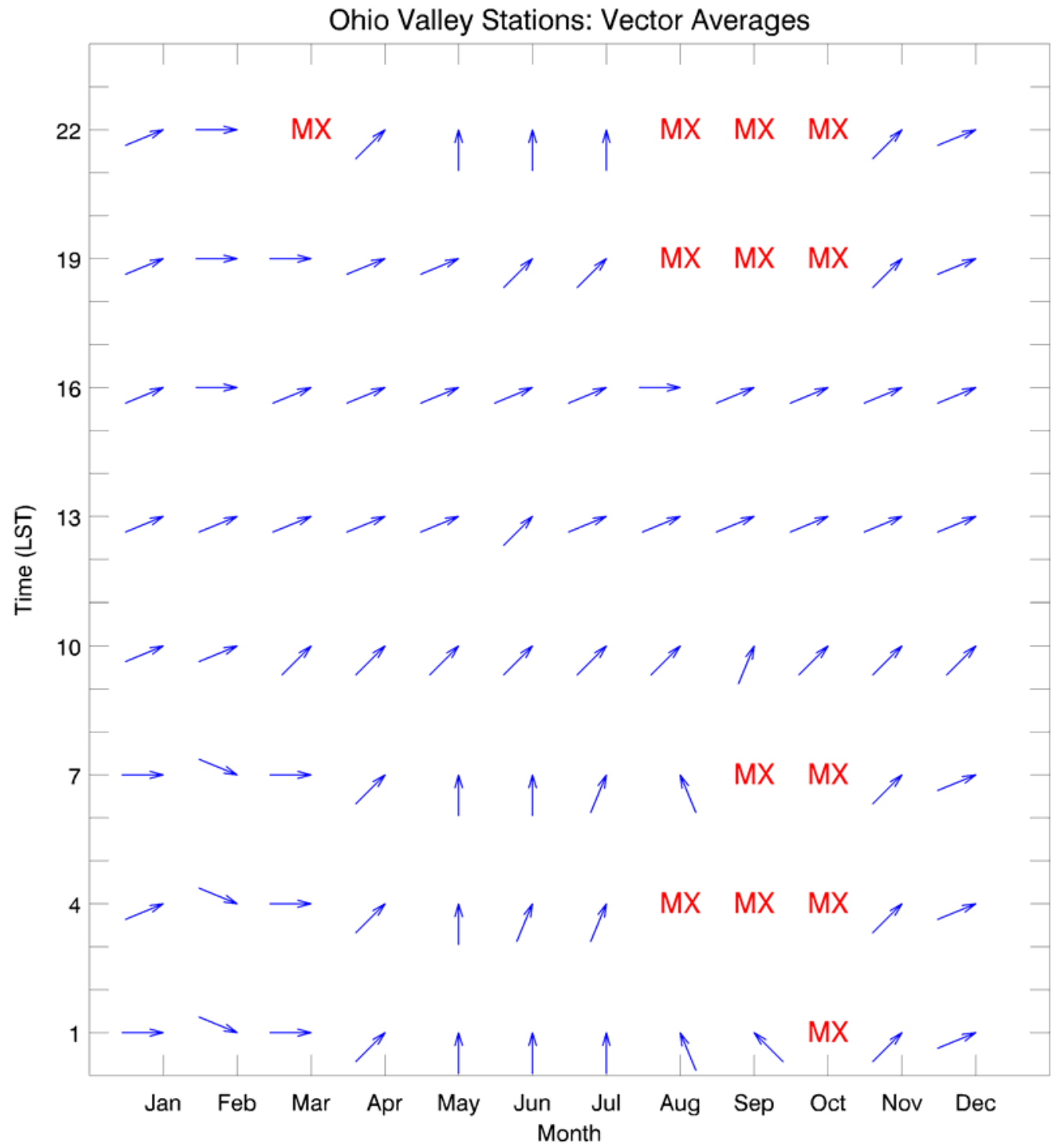

Figure 12: Variation of vector averages with month and time of day for the Ohio Valley sub-region. 


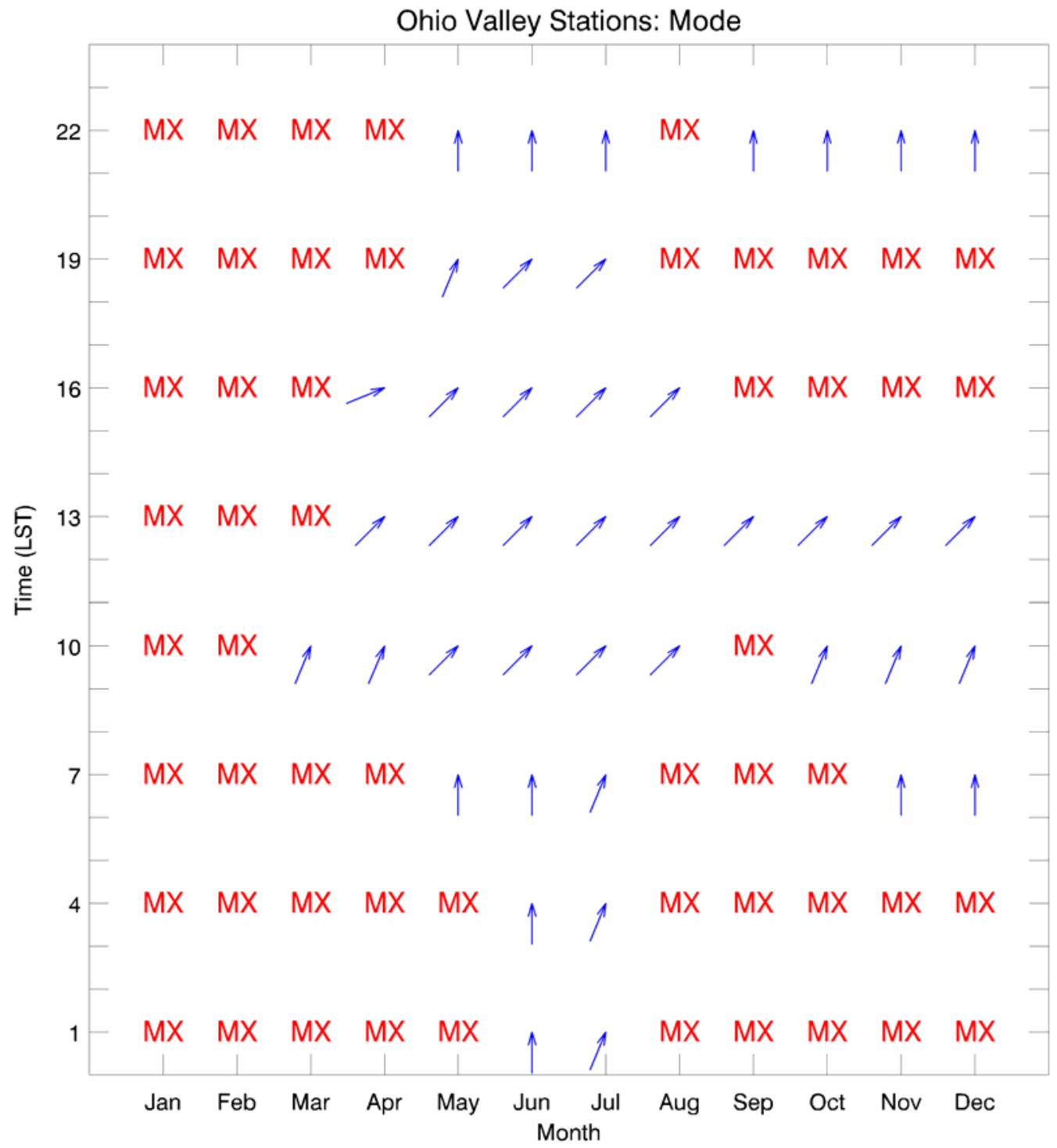

Figure 13: Variation of mode with month and time of day for the Ohio Valley sub-region. 


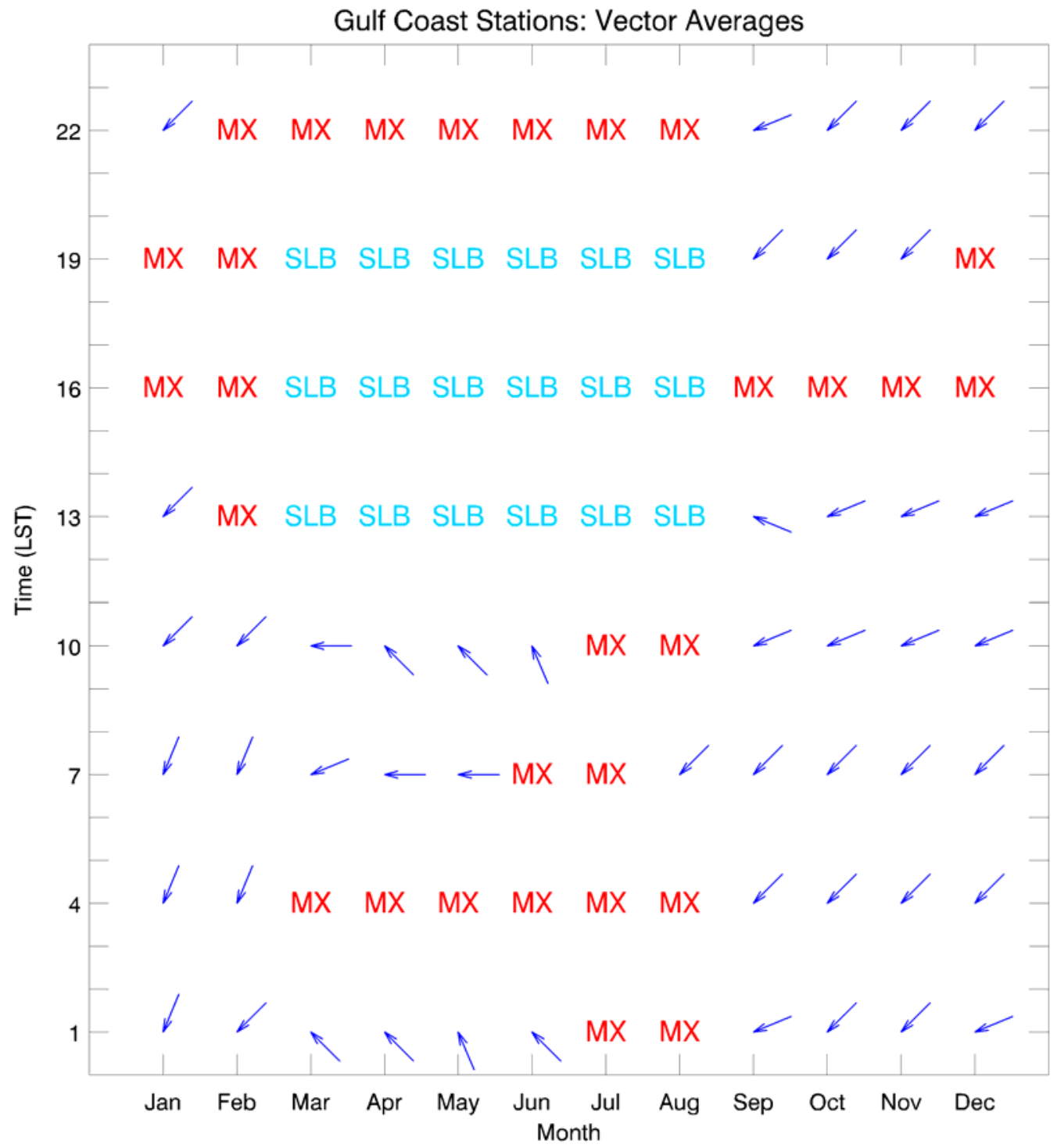

Figure 14: Variation of vector averages with month and time of day for the Gulf Coast sub-region. 


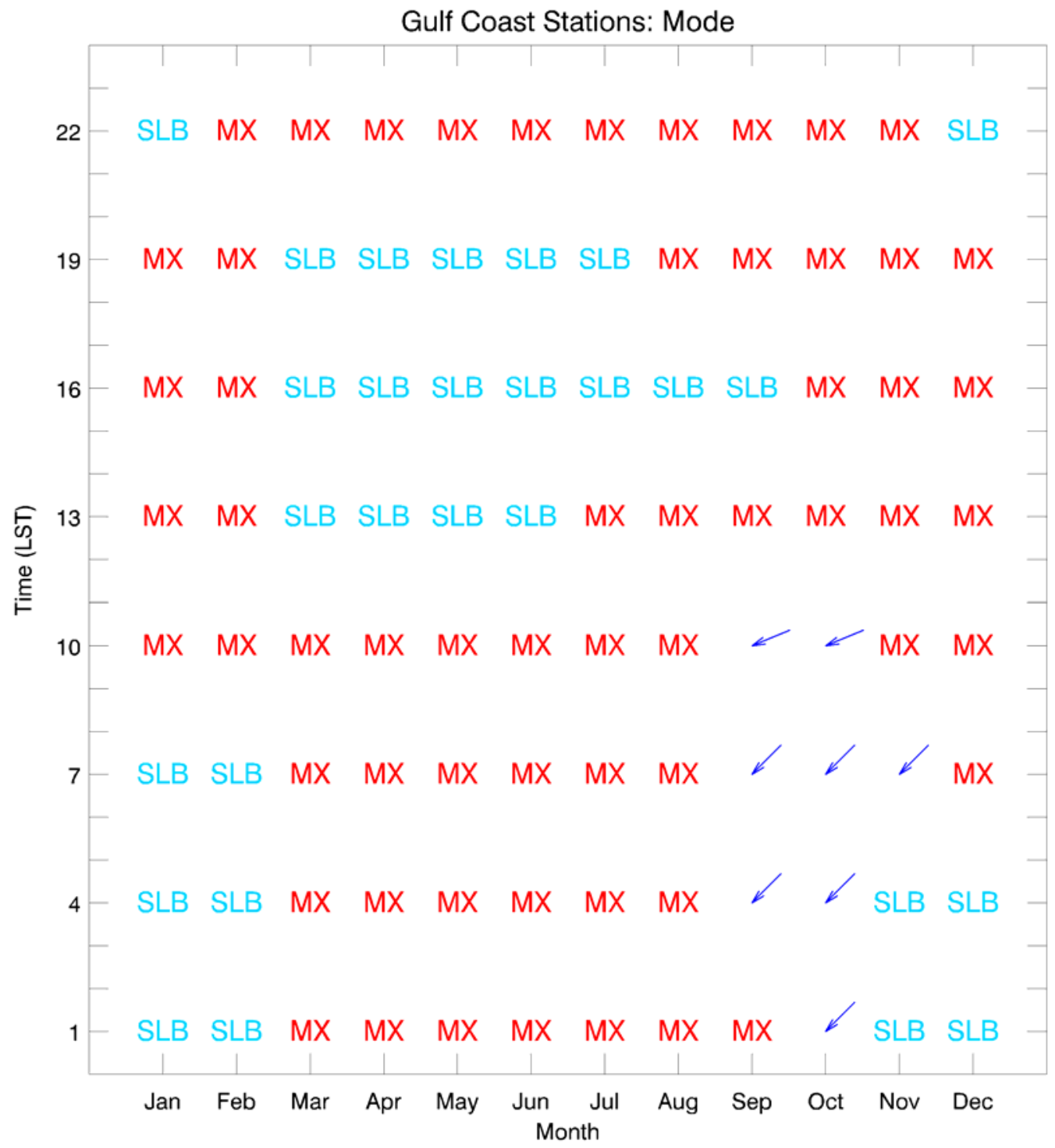

Figure 15: Variation of mode with month and time of day for the Gulf Coast sub-region. 